\title{
Antibiotic-modifying activity of riachin, a non-cyanogenic cyanoglycoside extracted from Bauhinia pentandra
}

This article was published in the following Dove Press journal:

Drug Design, Development and Therapy

15 June 2015

Number of times this article has been viewed

\author{
Pablo Antonio Maia \\ de Farias ${ }^{1,3}$ \\ Fernando Gomes \\ Figueredo ${ }^{2,3}$ \\ Aline Maria Brito Lucas ${ }^{3}$ \\ Rafael Barbosa de Moura ${ }^{3}$ \\ Henrique Douglas Melo \\ Coutinho ${ }^{2}$ \\ Tania Maria Sarmento \\ da Silva ${ }^{4}$ \\ Ana Luiza de Aguiar Rocha \\ Martin ${ }^{2,3}$ \\ Marta Maria de França \\ Fonteles' \\ 'Development and Technological \\ Innovation in Medicines, Universidade \\ Federal do Ceará - UFC, \\ Fortaleza-CE, ${ }^{2}$ College of Biomedicine, \\ Faculdade Leão Sampaio-FLS, ${ }^{3}$ College \\ of Pharmacy, Faculdade de Medicina \\ Estácio de Juazeiro do Norte-Estácio, \\ Juazeiro do Norte-CE, ${ }^{4}$ Department \\ of Molecular Sciences, Universidade \\ Federal Rural de Pernambuco, Recife, \\ PE, Brazil
}

Background: The search for new active compounds from the Brazilian flora has intensified in recent years, especially for new drugs with antibiotic potential. Accordingly, the aim of this study was to determine whether riachin has antibiotic activity in itself or is able to modulate the activity of conventional antibiotics.

Methods: A non-cyanogenic cyanoglycoside known as riachin was isolated from Bauhinia pentandra, and was tested alone and in combination with three antibiotics (clindamycin, amikacin, and gentamicin) against multiresistant bacterial strains (Escherichia coli, Pseudomonas aeruginosa, and Staphylococcus aureus).

Results: Riachin did not show significant antibiotic activity when tested alone against any strain $(P>0.05)$. However, when combined with conventional antibiotics, it showed drugmodifying activity against strains of $S$. aureus exposed to clindamycin $(P<0.001)$ as well as against $P$. aeruginosa exposed to amikacin $(P<0.001)$. Although riachin did not show direct antibiotic activity, it had synergistic activity when combined with amikacin or clindamycin. The mechanism of action of this synergism is under investigation.

Conclusion: The results of this work demonstrate that some substances of natural origin can enhance the effectiveness of certain antibiotics, which means a substantial reduction in the drug dose required and possibly in consequent adverse events for patients.

Keywords: riachin, Escherichia coli, Pseudomonas aeruginosa, Staphylococcus aureus

\section{Introduction}

Infectious diseases of bacterial origin are a recurrent problem in public health, and have a substantial impact on morbidity and mortality in populations in general. Therefore, in recent years, the pharmaceutical industry has been prompted to develop new antibiotic drugs, in particular because of the emergence of microorganisms resistant to conventional drugs. ${ }^{1}$ This occurs because bacteria have the genetic capacity to acquire and transmit resistance to the antibacterial agents currently available. There are various reports on bacterial isolates that are known for being sensitive to routinely used drugs, but have now become resistant to other medications available on the market. ${ }^{2,3}$ Consequently, pharmaceutical companies are searching for new strategies to supply the market with new antibiotics. The most common strategies involve altering the molecular structures of existing drugs, with the aim of making them more effective or able to recover their lost activity due to the presence of bacterial resistance mechanisms. ${ }^{4}$ Accordingly, natural products such as those of plant origin have been identified as not only having antibacterial activity but also as being able to potentiate antibiotic activity. ${ }^{5,6}$

The Brazilian flora is very diverse, and still has a large variety of species not yet studied; each year, new substances are identified in nature, and many of these may

\footnotetext{
Correspondence: Henrique Douglas Melo Coutinho

Universidade Regional do Cariri, Av Cel Antonio, Luis II6I, Pimenta, Crato,

Ceará, CEP 63100-000, Brazil

Tel +55883102 I2I2

Email hdmcoutinho@gmail.com
} 
have the potential to be developed as new drugs. Plants of Northeast Brazil under investigation include species of Bauhinia, among which Bauhinia forficata has been utilized by the people for many years, principally because of its hypoglycemic activity, a property reported back in the 1990s by various authors. ${ }^{7-9}$ Another species that has shown scientific relevance is Bauhinia pentandra, which has demonstrated antiulcer activity, ${ }^{10}$ and has an inhibitory effect on factor XIIa in the coagulation cascade. ${ }^{11,12}$

B. pentandra (Bong.) Vog. Ex Steud (Fabaceae) is known in Northeast Brazil as "mororo-de-espinho", and can be found in the Caatinga region and in caatinga-cerrado transition forests. The stem bark is widely used as a depurative tonic and in the treatment of diabetes. ${ }^{13}$ Among the substances identified in the species of Bauhinia, are beta-sitosterol and kaempferol3,7-dirhamnoside (kaempferitrin). ${ }^{14}$ Investigation of the root bark of $B$. pentandra (Fabaceae) led to isolation and characterization of a new cyanoglycoside called riachin. This drug has demonstrated antioxidant potential in 1,1-Diphenyl-2-picrylhydrazyl (DPPH) and 2,2'-azino-bis-3-ethylbenzthiazoline-6sulphonic acid (ABTS) tests, in addition to metal-chelating activity, including for ferrous $\left(\mathrm{Fe}^{2+}\right)$ ions. ${ }^{15}$

The cyanoglycosides are widely known for their toxicity, but some have pharmacological activity, for example, an antiallergic action, ${ }^{16}$ without toxic effects. However, the majority of cyanoglycosides in nature are cyanogenic, meaning they contain an alphanitrile group adjacent to a glycosidic bond, such that hydrolysis of these glycosides by glycosidases, followed by oxidation of the resultant cyanohydrin, releases the corresponding aldehyde or ketone and hydrocyanic acid.

Plants contain cyanogenic compounds are deemed not fit for animal or human consumption in their natural state, and can only be ingested if the cyanide has been eliminated by milling or heating.

Although riachin is a cyanoglycoside, the position of the cyano group is not next to the glycosidic bond of the molecule, so its hydrolysis does not result in the release of cyanide, which decreases its toxicity. Accordingly, riachin is found in a limited group of non-cyanogenic cyanoglycosides, such as simmondsin ${ }^{17}$ and laphoriside isolated from Lophira alata, a common plant in Africa, ${ }^{18}$ as well as the more recently isolated class of cyanoglycosides called ehretiosides, which have been demonstrated to have antagonistic activity against histamine. ${ }^{19}$ The basic structure of this class was defined ${ }^{20}$ and later characterized as a non-cyanogenic cyanoglycoside, but under specific conditions, it can release a small quantity of cyanide. ${ }^{21}$

Non-cyanogenic cyanoglycosides belong to a group of substances that are still little studied, but they appear to show different activities in various systems, including the immune and nervous systems, and have antibiotic activity.

The objective of this study was to investigate, using an in vitro model, the antibiotic and antibiotic-modifying activity of riachin, a cyanoglycoside extracted from $B$. pentandra (Bong.) Vog. Ex Steudas, and assess its potential as a therapeutic alternative for the treatment of bacterial infections, alone or in combination with other antibiotics, to reduce the utilization of drugs with more frequent adverse reactions.

\section{Materials and methods}

The molecular structure of riachin has been analyzed with support from the ChEMBL database, a strategic grant from the Wellcome Trust and the European Molecular Biology Laboratory (EMBL) for the field of chemogenomics. Access is free via the European Bioinformatics Institute (EBI, https:// www.ebi.ac.uk/chembl/), which is part of the EMBL and responsible for financing. EMBL-EBI makes data freely available from life science experiments that cover the entire spectrum of molecular biology. The ChEMBL is an open database manually fed from periodicals concerning small molecules. ${ }^{22,23}$

A search for similar molecules (having a minimum of $80 \%$ structural similarity to riachin) yielded six substances (Table 1). The activities of these substances as reported in

Table I Molecular characteristics of the six substances identified by the ChEMBL database with $80 \%$ or more molecular similarity to riachin

\begin{tabular}{lllllllll}
\hline ChEMBL ID & Synonymous & $\begin{array}{l}\text { Similarity } \\
(\%)\end{array}$ & $\begin{array}{l}\text { Apparent } \\
\text { molecular weight }\end{array}$ & ALogP & PSA & HBA & HBD & $\begin{array}{l}\text { QED } \\
\text { weighted }\end{array}$ \\
\hline ChEMBLI967788 & SID57I895 & 100 & 329.30 & -2.51 & 163.63 & 9 & 6 & 0.31 \\
ChEMBLI8I7899 & Griffonin & 100 & 329.30 & -2.51 & 163.63 & 9 & 6 & 0.31 \\
ChEMBL2268556 & No synonyms & 89.09 & 375.37 & -2.6 & 161.86 & 10 & 5 & 0.32 \\
ChEMBLI997657 & SID444912 & 89.09 & 375.37 & -2.6 & 161.86 & 10 & 5 & 0.32 \\
ChEMBLI5054I6 & SID2240I404 & 89.09 & 375.37 & -2.6 & 161.86 & 10 & 5 & 0.32 \\
ChEMBL2268555 & No synonyms & 80.57 & 551.54 & -0.35 & 197.39 & 13 & 5 & 0.14 \\
\hline
\end{tabular}

Abbreviations: EMBL, European Molecular Biology Laboratory; ALogP, solubility octanol/water; PSA, polar surface area; HBA, hydrogen bond acceptor; HBD, hydrogen bond donor; QED, quantitative estimation of drug-likeness. 
Table 2 Activity of molecules similar to riachin identified by ChEMBL

\begin{tabular}{llll}
\hline ChEMBL ID & Synonymous & Reported activity & Reference \\
\hline ChEMBLI 967788 & SID57I895 & Virtual testing & No related references \\
ChEMBLI8I7899 & Griffonin & Antimicrobial (bacteria and yeast) & Mazimba et al $\left.\right|^{46}$ \\
ChEMBL2268556 & No synonyms & Antifeedant, antifungal, and insecticide & Abbassy et al $^{47}$ \\
ChEMBLI997657 & SID4449I2 & Virtual testing & No related references \\
ChEMBLI5054I6 & SID2240I404 & Antimicrobial (bacteria and yeast) & Mazimba et al ${ }^{46}$ \\
ChEMBL2268555 & No synonyms & Antifeedant, antifungal, and insecticide & Abbassy et al $^{47}$ \\
\hline
\end{tabular}

Abbreviation: EMBL, European Molecular Biology Laboratory.

the publications (Table 2) were considered to define the research procedures. Considering the evidence for antimicrobial activity of similar molecules, it was decided to investigate riachin as an antimicrobial agent or a modulator of antimicrobial activity.

\section{Bacteria}

The bacterial strains utilized were Escherichia coli, Pseudomonas aeruginosa, and Staphylococcus aureus with the resistance profiles identified in Table 3. All strains were maintained on heart infusion agar (Difco Laboratories Ltd, West Molesey, UK). Before the assays, the strains were grown for 18 hours at $37^{\circ} \mathrm{C}$ in brain heart infusion broth (Difco Laboratories Ltd). All bacteria used in this work were previously reported as having the existence of efflux pumps sensitive to phenothiazines. ${ }^{24,25}$

\section{Drugs}

Gentamicin, amikacin, and clindamycin were obtained from Sigma Chemical Co (St Louis, MO, USA). The solutions were prepared according to the recommendations of the National Committee for Clinical Laboratory Standards. ${ }^{26}$ First, $1.2 \mathrm{~kg}$ of $B$. pentandra (Bong.) Vog. exSteud. (Fabaceae) powdered root bark were extracted with ethanol in a Soxhlet apparatus at the Molecular Sciences Laboratory, Universidade Federal Rural de Pernambuco. The extract was concentrated under vacuum in a rotary evaporator. After being allowed to stand in the refrigerator, the crude residue had the appearance of a light brown precipitate (2.46\%) and was identified by spectrophotometric methods as the cyanoglycoside riachin (Figure 1). ${ }^{15}$

\section{Determination of MIC and modulation of antibiotic activity}

The minimal inhibitory concentration (MIC) was determined by the broth microdilution assay using an inoculum of $100 \mu \mathrm{L}$ for each strain suspended in brain heart infusion broth with a concentration of $10^{5}$ colony-forming units $/ \mathrm{mL}$ in 96-well microtiter plates, with two-fold serial dilutions. Next, $100 \mu \mathrm{L}$ of riachin were added to each well, where the final concentrations were in the range of $8-512 \mu \mathrm{g} / \mathrm{mL}$. For the controls, the standard antibiotics (amikacin, gentamicin, and clindamycin) were used at final concentrations of $8-512 \mu \mathrm{g} / \mathrm{mL}$. The plates were incubated at $35^{\circ} \mathrm{C}$ for 24 hours, after which growth was assessed using the resazurin assay. MIC was determined as the lowest concentration that inhibited bacterial growth.

To evaluate the ability of riachin to modify the action of the antibiotics, the MICs of gentamicin and amikacin (aminoglycosides) and clindamycin (lincosamide) were determined in the presence and absence of riachin in sterile microplates. The antibiotics were evaluated at concentrations of $2.88-2,500 \mu \mathrm{g} / \mathrm{mL}$. All antibiotics tested were obtained from Sigma-Aldrich.

Riachin was dissolved in $10 \%$ brain heart infusion broth at a subinhibitory concentration, which was determined by

Table 3 Origin of bacterial strains and antibiotic resistance profile

\begin{tabular}{lll}
\hline Bacteria & Origin & Resistance profile \\
\hline Escherichia coli 27 & Urine culture & Cefadroxil, cephalexin, cefaclor, cefepime, ceftriaxone, \\
ampicillin-sulbactam & Not available \\
Staphylococcus aureus 10 & Not available & Cefadroxil, cephalexin, cefaclor, oxacillin, penicillin, \\
& Rectal swab & ampicllin, amoxicillin, moxifloxacin, ciprofloxacin, \\
levofloxacin, ampicillin-sulbactam, amoxicillin-clavulanic acid, & erythromycin, clarithromycin, azithromycin, clindamycin \\
Staphylococcus aureus ATCC 25923 & & Not available \\
Pseudomonas aeruginosa 03 & Cefepime, ceftazidime, ciprofloxacin, levofloxacin, & meropenem, imipenem, and piperacillin-tazobactam \\
Pseudomonas aeruginosa ATCC 25853 & Rectal swab & Not available
\end{tabular}




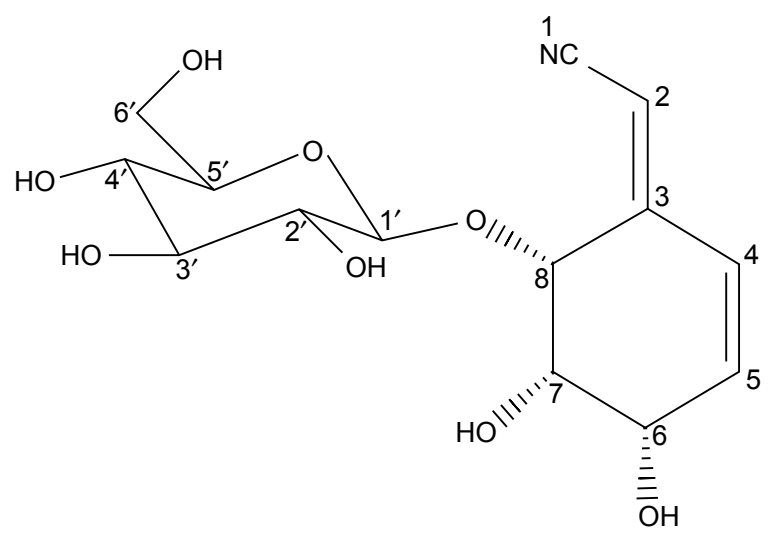

Figure I Chemical structure of riachin.

evaluation of its MIC, where the compound was diluted to an eight-fold reduced MIC (MIC/8). Antibiotic solutions were prepared by addition of sterile distilled water at double the concentration $(5,000 \mu \mathrm{g} / \mathrm{mL})$ in relation to the initial concentration defined and volumes of $100 \mu \mathrm{L}$ diluted serially $1: 1$ in $10 \%$ brain heart infusion broth. Next, $100 \mu \mathrm{L}$ of culture containing a bacterial suspension diluted 1:10 were added to each well. The same controls utilized in the evaluation of MIC for the sample were utilized for modulation..$^{24}$ The plates were incubated at $35^{\circ} \mathrm{C}$ for 24 hours, after which growth was measured by the resazurin assay. The antibacterial assay was performed in triplicate and the results were expressed as the mean of replicates.

\section{Statistical analysis}

Statistical analysis of the data was done using the GraphPad Prism ${ }^{\circledR}$ version 4.0 for Windows ${ }^{\circledR}$ software (GraphPad Software,
San Diego, CA, USA). Data showing a parametric distribution were evaluated by analysis of variance. All data are shown as the mean \pm standard error of the mean, and the critical level considered to reject the null hypothesis was $0.05(P<0.05)$.

\section{Results and discussion}

The MIC of the test compound against the standard bacterial strains (E. coli ATCC 25922, S. aureus ATCC 25923, and $P$. aeruginosa ATCC 25853) showed the same result, ie, an MIC $\geq 1,024 \mu \mathrm{g} / \mathrm{mL}$, with the exception of the sample against E. coli 25922, which had an MIC of $128 \mu \mathrm{g} / \mathrm{mL}$. No clinically relevant activity was demonstrated, according to the limits established by the protocol. ${ }^{24} \mathrm{~A}$ pilot assay utilizing only dimethyl sulfoxide was performed, in which no antibiotic activity or antibiotic-modifying activity was observed, indicating that it had no influence at the concentration utilized $(1.0 \%){ }^{27}$

Figure 2 shows the MICs for the aminoglycosides and for clindamycin in the presence and absence of riachin $\left(\mathrm{C}_{14} \mathrm{H}_{19} \mathrm{NO}_{8}\right)$ at an $\mathrm{MIC} / 8$ concentration of $128 \mu \mathrm{g} / \mathrm{mL}$. Thus, a significant synergistic effect $(P<0.001)$ was seen against $P$. aeruginosa when amikacin was combined with the test compound and against $S$. aureus with the combination of riachin and clindamycin. The other results were not statistically significant $(P>0 / 05)$.

Other studies using natural products or active substances from plants with antibiotic activity have obtained satisfactory results. ${ }^{28,29}$ These results are in agreement with other reports in the literature showing that combinations of natural products and antibiotics can reduce antibiotic resistance. ${ }^{25}$

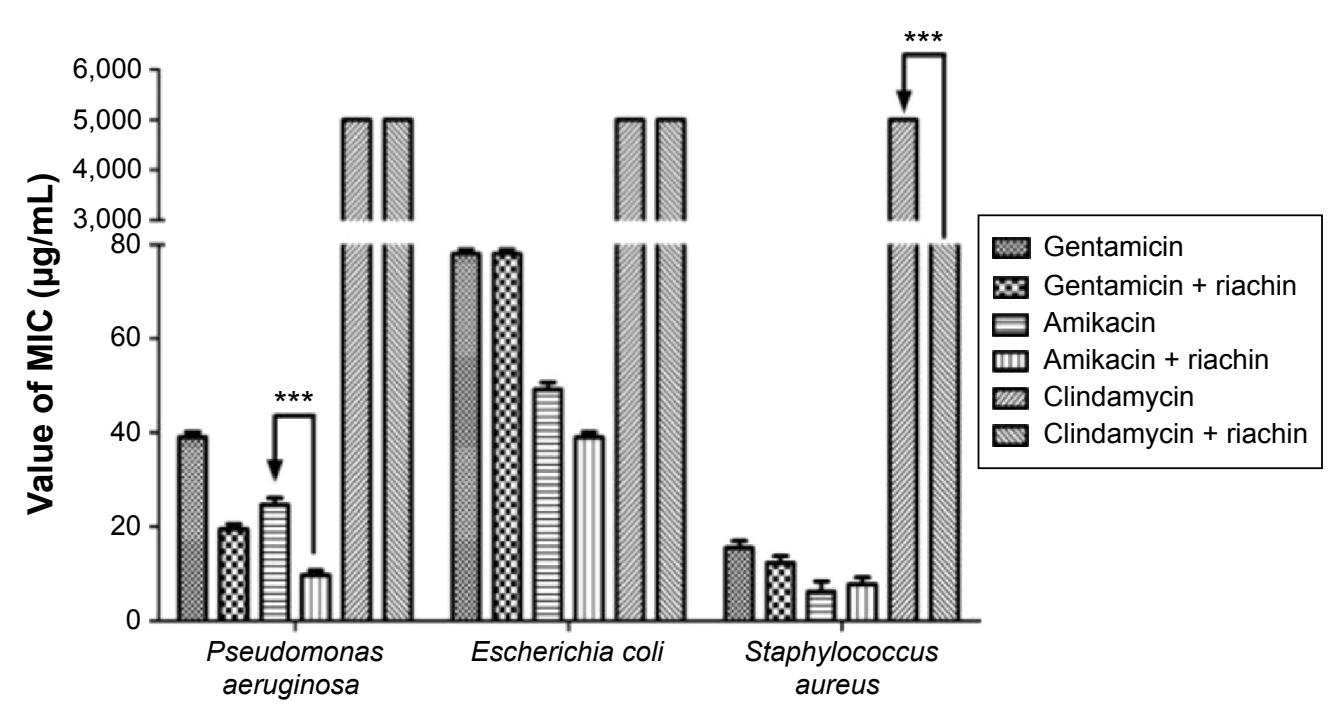

Figure 2 MIC of aminoglycosides and clindamycin in the presence and absence of riachin (Cl4HI9NO8) at MIC/8 (I28 $\mu$ g/mL), against Pseudomonas aeruginosa and Staphylococcus aureus and MIC/8 $(32 \mu \mathrm{g} / \mathrm{mL})$ against Escherichia coli.

Note: $* * * P<0.001$.

Abbreviations: MIC, minimal inhibitory concentration; MIC/8, eight-fold reduced minimal inhibitory concentration. 
Few studies of $B$. pentandra have been published, and none have investigated the activity of the plant or its components against microorganisms. Other species of Bauhinia have shown some antibiotic activity, ${ }^{30}$ the most closely related being Bauhinia tomentosa, B. vahlii, ${ }^{31}$ B. kockiana, ${ }^{32}$ and B. purpurea $\mathrm{L} \cdot{ }^{33}$ However, the literature is still scarce with regard to the activity of plants of this genus against microorganisms. Since riachin can be isolated from the root bark of $B$. pentandra in good quantity $(2.46 \%),{ }^{15}$ it can be readily obtained for studies of its antibiotic activity.

Since the 1960s when the aminoglycosides were first introduced to the market, a number of infections caused by Gram-negative bacteria have been able to be treated more effectively, but at the expense of side effects, in particular nephrotoxicity ${ }^{34,35}$ and ototoxicity. ${ }^{36-38}$ The main adverse effects of clindamycin are gastrointestinal disturbance, which can manifest in the form of pseudomembranous colitis, ${ }^{39}$ and severe diarrhea. These side effects are relevant factors to be considered when treating patient with these agents. Thus, combination of riachin with amikacin or clindamycin could be an alternative to minimize the side effects of these antibiotics, since their combination leads to a synergistic effect and significant reduction in MIC, meaning that the dose needed for therapeutic success can be lowered.

The principal drug resistance mechanisms of bacteria involve modifications in the target bond in the ribosome, the efflux pump, or enzymatic inactivation of the drug. ${ }^{40}$ Clindamycin is often used in skin infections, particularly when there is resistance to penicillins. ${ }^{41}$

The possible difference in activity of riachin against the $P$. aeruginosa strain when combined with amikacin and gentamicin is probably due to the structural differences in these aminoglycosides; both are hydrophilic molecules formed by an aminocyclitol ring connected to one or more amino sugars through a glycosidic bond. In most of the drugs with these characteristics and which are clinically useful - the aminocyclitol group is 2-deoxy-streptamine, which can be bisubstituted at position 4 and 5 , or 4 and $6,{ }^{42}$ so being able to influence the the polarity, solubility, and consequently, the absorption of these drugs.

Our results are consistent with those found in the literature, ${ }^{43}$ and demonstrate that $E$. coli strains are more resistant to the action of natural products, such as extracts and essential oils. ${ }^{43}$ This could be due to the presence of other resistance mechanisms, including the efflux pump, production of enzymes that cleave the $\beta$-lactam ring ( $\beta$-lactamases), and changes in penicillin-binding proteins. ${ }^{44,45}$

\section{Conclusion}

The use of antibiotics is routine and necessary in clinical practice, but development of resistance makes it difficult to achieve the desired results in many patients, even in patients with low risk of severe adverse reactions for some drug classes, particularly the aminoglycosides. Accordingly, the activity of amikacin against $P$. aeruginosa and the activity of clindamycin against $S$. aureus could be potentiated if these antibiotics were combined with riachin. Due to the high polarity of riachin, this substance is likely to interact with efflux pumps in bacteria; tests are being developed to investigate this possibility using specific bacterial strains with defined and super-expression of efflux pumps. Further studies should be conducted, in particular studies of new combinations containing this natural drug and other bacterial strains. This compound may have a role as an adjuvant in some pharmaceutical formulations used to treat infection.

\section{Disclosure}

The authors report no conflicts of interest in this work. The authors alone are responsible for the content and writing of the paper.

\section{References}

1. Silva NCC, Junior AF. Biological properties of medicinal plants: a review of their antimicrobial activity. J Venom Anim Toxins Incl Trop Dis. 2010;16:402-413.

2. Nascimento GG, Locatelli J, Freitas PC, Silva GL. Antibacterial activity of plant extracts and phytochemicals on antibiotic-resistant bacteria. Braz J Microbiol. 2000;31:247-256.

3. Sakagami Y, Kajimura K. Bactericidal activities of disinfectants against vancomycin-resistant enterococci. J Hosp Infect. 2002;50:140-144.

4. Chartone-Souza E. Bactérias ultra-resistentes: uma guerra quase perdida. [Ultra-resistant bacteria: an almost lost war]. Cienc Hoje. 1998;23: 27-35. Portuguese.

5. Tintino SR, Guedes GMM, da Cunha FAB, et al. Avaliação in vitro da atividade antimicrobiana e moduladora dos extratos etanólico e hexânico de bulbo de Costus arabicus. [In vitro evaluation of antimicrobial activity and modulating the ethanol and hexane extracts of Costus arabicus bulb]. Bioscience Journal. 2013;29:732-738. Portuguese.

6. Gibbons S. Anti-staphylococcal plant natural products. Nat Prod Rep. 2004;21:263-277.

7. Russo EM, Reichelt AA, De-Sa JR, et al. Clinical trial of Myrcia uniflora and Bauhinia forficata leaf extracts in normal and diabetic patients. Braz J Med Biol Res. 1990;23:11-20.

8. Silva FR, Szpoganicz B, Pizzolatti MG, Willrich MA, De Sousa E. Acute effect of Bauhinia forficata on serum glucose levels in normal and alloxan-induced diabetic rats. J Ethnopharmacol. 2002;83:33-37.

9. Lino Cde S, Diógenes JP, Pereira BA, et al. Antidiabetic activity of Bauhinia forficata extracts in alloxan-diabetic rats. Biol Pharm Bull. 2004;27:125-127.

10. Akhtar AH, Ahmad KU. Anti-ulcerogenic evaluation of the methanolic extracts of some indigenous medicinal plants of Pakistan in aspirinulcerated rats. J Ethnopharmacol. 1995;46(1):1-6.

11. Sampaio CA, Motta G, Sampaio MU, et al. Action of plant proteinase inhibitors on enzymes of the kallikrein kinin system. Agents Actions Suppl. 1992;36:191-199.

12. Sampaio CA, Oliva ML, Tanaka AS, Sampaio MU. Proteinase inhibitors in Brazilian Leguminosae. Mem Inst Oswaldo Cruz. 1991; 86 Suppl 2:207-209. 
13. Agra MF, Silva KN, Basílio IJLD, França PF, Barbosa-Filho JM. Survey of medicinal plants used in the region Northeast of Brazil. Rev Bras Farmacogn. 2008; 18:472-508.

14. da Silva KL, Biavatti MW, Leite SN, Yunes RA, Delle Monache F, Cechinel Filho V. Phytochemical and pharmacognostic investigation of Bauhinia forficata Link (Leguminosae). Z Naturforsch C. 2000;55:478-480.

15. Silva TMS, Lins ACS, Sarmento-Filha MJ, Ramos CS, Agra MF, Camara CA. Riachin, a new cyanoglucoside from Bauhinia pentandra and its antioxidant activity. Chem Nat Compd. 2013;49: 685-690.

16. Yoshikawa M, Shimada H, Shimoda H, Matsuda H, Yamahara J, Murakami N. Rhodiocyanosides A and B, new antiallergic cyanoglycosides from Chinese natural medicine "si lie hong jing tian", the underground part of Rhodiola quadrifida (Pall.) Fisch. et Mey. Chem Pharm Bull (Tokyo). 1995;43:1245-1247.

17. Elliger CA, Waiss AC, Lundin RE. Simmondsin, an unusual 2cyanomethylenecyclohexyl glucoside from Simmondsia californica. J Chem Soc Perkin Trans. 1973;1:2209-2212.

18. Murakami A, Ohigashi H, Tanaka S, et al. Bitter cyanoglucosides from Lophira alata. Phytochemistry. 1993;32:1461-1466.

19. Simpol LR, Otsuka H, Ohtani K, Kasai R, Yamasaki K. Nitrile glucosides and rosmarinic acid, the histamine inhibitor from Ehretia philippinensis. Phytochemistry. 1994;36:91-95.

20. Sosa A, Winternitz F, Wylde R, Pavia AA. Structure of a cyanoglucoside of Lithospermum purpureo-caeruleum. Phytochemistry. 1977; $16: 1-12$.

21. Lechtenberg M, Nahrstedt A. Cyanogenic glycosides. In: Ikan R, editor. Naturally Occurring Glycosides, Chichester, UK: John Wiley; 1999.

22. Gaulton A, Bellis LJ, Bento AP, et al. ChEMBL: a large-scale bioactivity database for drug discovery. Nucleic Acids Res. 2012;40 Database issue:D1100-D1107.

23. Bento AP, Gaulton A, Hersey A, et al. The ChEMBL bioactivity database: an update. Nucleic Acids Res. 2014;42 Database issue:D1083-D1090.

24. Coutinho HD, Costa JG, Lima EO, Falcao-Silva VS, Siqueira-Junior JP. Potentiating effect of Mentha arvensis and chlorpromazine in the resistance to aminoglycosides of methicillin-resistant Staphylococcus aureus. In Vivo. 2009;23:287-289.

25. Coutinho HD, Costa JG, Lima EO, Falcao-Silva VS, Siqueira-Junior JP. Enhancement of the antibiotic activity against a multiresistant Escherichia coli by Mentha arvensis L. and chlorpromazine. Chemotherapy. 2008:54:328-330.

26. NCCLS. Methods for Dilution Antimicrobial Susceptibility Tests for Bacteria That Grow Aerobically; Approved Standard. 6th ed. Wayne, PA: NCCLS; 2003.

27. Houghton PJ, Howes MJ, Lee CC, Steventon G. Uses and abuses of in vitro tests in ethnopharmacology: visualizing an elephant. J Ethnopharmacol. 2007;110:391-400.

28. Darwish RM, Aburjai TA. Effect of ethnomedicinal plants used in folklore medicine in Jordan as antibiotic resistant inhibitors on Escherichia coli. BMC Complement Altern Med. 2010;10:9.

29. Raja RD, Jeeva S, Prakash JW, Antonisamy JM, Irudayaraj V. Antibacterial activity of selected ethnomedicinal plants from South India. Asian Pac J Trop Med. 2011;4:375-368.
30. Cechinel Filho V. Chemical composition and biological potential of plants from the genus Bauhinia. Phytother Res. 2009;23:1347-1354.

31. Dugasani S, Balijepalli MK, Tandra S, Pichika MR. Antimicrobial activity of Bauhinia tomentosa and Bauhinia vahlii roots. Pharmacogn Mag. 2010;6:204-207.

32. Chew YL, Chan EW, Tan PL, Lim YY, Stanslas J, Goh JK. Assessment of phytochemical content, polyphenolic composition, antioxidant and antibacterial activities of Leguminosae medicinal plants in Peninsular Malaysia. BMC Complement Altern Med. 2011;11:12.

33. Zaki AA, Shaaban MI, Hashish NE, Amer MA, Lahloub MF. Assessment of anti-quorum sensing activity for some ornamental and medicinal plants native to Egypt. Sci Pharm. 2013;81:251-258.

34. Quamme GA. Renal handling of magnesium: drug and hormone interactions. Magnesium. 1986;5:248-272.

35. Kang HS, Kerstan D, Dai L, Ritchie G, Quamme GA. Aminoglycosides inhibit hormone-stimulated $\mathrm{Mg} 2+$ uptake in mouse distal convoluted tubule cells. Can J Physiol Pharmacol. 2000;78:595-602.

36. Forge A, Fradis M. Structural abnormalities in the stria vascularis following chronic gentamicin treatment. Hear Res. 1985;20:233-244.

37. Forge A, Li L, Corwin JT, Nevill G. Ultrastructural evidence for hair cell regeneration in the mammalian inner ear. Science. 1993;259:1616-1619.

38. Kusunoki T, Cureoglu S, Schachern PA, et al. Effects of aminoglycoside administration on cochlear elements in human temporal bones. Auris Nasus Larynx. 2004;31:383-388.

39. Worret WI, Fluhr JW. [Acne therapy with topical benzoyl peroxide, antibiotics and azelaic acid]. J Dtsch Dermatol Ges. 2006;4:293-300. German.

40. Leclercq R. Mechanisms of resistance to macrolides and lincosamides: nature of the resistance elements and their clinical implications. Clin Infect Dis. 2002;34:482-492.

41. Fiebelkorn KR, Crawford SA, McElmeel ML, Jorgensen JH. Practical disk diffusion method for detection of inducible clindamycin resistance in Staphylococcus aureus and coagulase-negative staphylococci. J Clin Microbiol. 2003;41:4740-4744.

42. Magnet S, Blanchard JS. Molecular insights into aminoglycosides action and resistance. Chem Rev. 2005;105:477-498.

43. Veras HNH. Caracterização química e avaliação da atividade antimicrobiana e antiinflamatória tópica do óleo essencial de Lippia sidoides Cham. (verbenaceae). [Chemical characterization and evaluation of topical anti-inflammatory and antimicrobial activity of essential oil of Lippia sidoides Cham]. Dissertação de Mestrado, Universidade Regional do Cariri - URCA. 2011. Portuguese.

44. Bush K. The impact of beta-lactamases on the development of novel antimicrobial agents. Curr Opin Investig Drugs. 2002;3:1284-1290.

45. Enright MC, Robinson DA, Randle G, Feil EJ, Grundmann H, Spratt BG. The evolutionary history of methicillin-resistant Staphylococcus aureus (MRSA). Proc Natl Acad Sci U S A. 2002;99:7687-7692.

46. Mazimba O, Majinda RR, Modibedi C, Masesane IB, Cencič A, Chingwaru W. Tylosema esculentum extractives and their bioactivity. Bioorg Medicinal Chem. 2011;19(17):5225-5230.

47. Abbassy MA, Abdelgaleil SAM, Belal A-SH, Rasoul MAAA. Insecticidal, antifeedant and antifungal activities of two glucosides isolated from the seeds of Simmondsia chinensis. Industrial Crops and Products. 2007;26(3):345-350.
Drug Design, Development and Therapy

\section{Publish your work in this journal}

Drug Design, Development and Therapy is an international, peerreviewed open-access journal that spans the spectrum of drug design and development through to clinical applications. Clinical outcomes, patient safety, and programs for the development and effective, safe, and sustained use of medicines are a feature of the journal, which

\section{Dovepress}

has also been accepted for indexing on PubMed Central. The manuscript management system is completely online and includes a very quick and fair peer-review system, which is all easy to use. Visit http://www.dovepress.com/testimonials.php to read real quotes from published authors. 